and D. George (eds.)

\title{
Long-term dynamics (1990 to 2004) of the polychaete fauna from the sublittoral soft-bottoms off Punta Coloso (Antofagasta), northern Chile
}

\author{
FRANKLIN D. CARRASCO and RODRIGO A. MORENO \\ Departamento de Oceanografía, Facultad de Ciencias Naturales y Oceanográficas, Universidad de Concepción, \\ Casilla 160-C, Concepción, Chile. E-mail: fcarrasc@udec.cl
}

\begin{abstract}
SUMMARY: Long-term monitoring (1990 to 2004) at four stations (50 to $60 \mathrm{~m}$ depth) off Punta Coloso, Antofagasta, northern Chile, has allowed us to study temporal changes in the sublittoral macrobenthic polychaete infauna composition and abundance. The numerical contribution of the polychaete fraction to the total fauna was high (65 to 93\%), whereas biomass was smaller and variable (20 to 85\%). The number of invertebrate species collected per cruise was relatively low (40 to 90 species) and the number of polychaete species ranged from 18 to 37 per cruise (mean $=29.9$ ), with a cumulative number of 56 polychaete species. The most abundant species collected included the small-sized Aricidea pigmentata Carrasco (26.5\%), Magelona phyllisae Jones (22.7\%), Paraprionospio pinnata (Ehlers) (13.5\%), Tharyx longisetosa Hartmann-Schröder $(12.1 \%)$, and Prionospio peruana Hartmann-Schröder (11.8\%). Clear general patterns or tendencies are not seen in temporal variations of polychaete fauna nor when analyzing the seasons individually. $P$. pinnata was the only dominant species to show a general tendency in abundance fluctuations. Although the study period included two El Niño events (1991-1992 and 1997-1998), a clear dynamic was not seen in either abundance or dominant species. The analyzed data validate or corroborate high stability or persistence over time that has been suggested for polychaete fauna in the study area. Such stability or persistence exists in spite of high seasonal variability and interannual fluctuations in the region's oceanographic conditions.
\end{abstract}

Keywords: polychaete infauna, long-term dynamics, persistence, sublittoral, Chile.

RESUMEN: DinÁMICA DE LARGO PLAZO (1990-2004) DE LA FAUNA DE POLIQUETOS DE LOS FONDOS SUBLITORALES BLANDOS FRENTE a Punta Coloso (ANTOFagasta), NORTE DE Chile. - La vigilancia de largo plazo (1990 a 2004), de la infauna de poliquetos de cuatro estaciones sublitorales $(50$ a $60 \mathrm{~m}$ de profundidad) frente a Punta Coloso, Antofagasta, norte de Chile, ha permitido estudiar sus cambios en composición y abundancia. La contribución numérica de la fracción poliquetos a la fauna total fue alta (entre $65 \%$ y $93 \%$ ), mientras a la biomasa total fue menor y variable $(20 \%-85 \%)$. El número de especies de invertebrados por crucero fue relativamente bajo ( 40 a 90 especies) y el número de especies de poliquetos varió entre 18 y 37 por crucero (media $=29,9$ ) y un número acumulativo de especies igual a 56 . Las especies mas abundantes fueron Aricidea pigmentata Carrasco (26,5\%), Magelona phyllisae Jones (22,7\%), Paraprionospio pinnata (Ehlers) (13,5\%), Tharyx longisetosa Hartmann-Schröder $(12,1 \%)$ y Prionospio peruana Hartmann-Schröder $(11,8 \%)$. Las variaciones temporales de la fauna de poliquetos, no muestra patrones o tendencias claras, como tampoco cuando se analizan cada una de las estaciones por separado. De las fluctuaciones de la abundancia de las especies dominantes, tampoco es posible apreciar tendencias, a excepción de la conducta de los números de P. pinnata. La presencia de dos eventos El Niño (1991-1992 y 1997-1998) tampoco se reflejan con alguna claridad en la dinámica de la abundancia de las diferentes estaciones como de las especies dominantes. Los datos aquí analizados validan la persistencia y alta estabilidad temporal sugerida para la fauna de poliquetos del área de estudio, a pesar de la alta variabilidad ambiental señalada para la región.

Palabras clave: poliquetos de la endofauna, dinámica a largo plazo, persistencia, sublitoral, Chile.

\section{INTRODUCTION}

Marine infaunal benthic assemblages are subject to a variety of physical disturbances, which are manifested on different scales (Zajac et al., 1998; Widdicombe and Austen, 2001). Macroscale physical disturbances (i.e. storms, hypoxias) that affect square kilometres; natural disturbances, biological 
in origin and usually microscale (i.e. bioturbation by mobile organisms) that affect square metres or square centimetres (see Probert, 1984; Widdicombe and Austen, 2001); and anthropogenic influences (i.e. trawling, dredging) (Thrush and Dayton, 2002) are credited with maintaining the heterogeneity of soft-bottomed environments and the large year-toyear variations in macrobenthic marine communities of shallow and estuarine areas (Boesch et al., 1976; Buchanan et al., 1978; Holland, 1985).

Long-term time series studies of temporal variations and benthic community variability have revealed periods of stability and persistence as well as others of instability due to physical disturbances affecting species abundance and richness (see Lie and Evans, 1973; Buchanan and Moore, 1986; Dauvin and Ibanez, 1986). At present, only one study has looked at medium-term variations in seasonal patterns (i.e. abundance, biomass, diversity) for the south-eastern Pacific. This study, which considers the polychaete fraction of the sublittoral macrobenthos off Punta Coloso (Antofagasta, northern Chile) (Carrasco, 1997) suggests a high level of stability and persistence over time for the benthic polychaete assemblage in spite of continuous physical disturbances of different scales (i.e. coastal upwellings, ENSO episodes) (see Arntz et al., 1991; Arntz and Fahrbach, 1996). Nevertheless, this study indicates the importance of deeper or longer-term analysis of observed patterns in order to validate the results obtained.

The objective of the present study is to examine temporal variations and persistence/stability (sensu Lewontin, 1969; Margalef, 1969) in a 15-year time series (1990-2004) of the ecological structure of the benthic polychaete fauna off Punta Coloso, northern Chile, based on Carrasco's 1997 study. Now that data are available from a much longer time period, we hope to validate the hypothesis that low polychaete fauna persistence/stability in the sublittoral soft-bottoms off Punta Coloso is due to high environmental variability.

\section{MATERIALS AND METHODS}

The continental shelf off northern Chile, at Punta Coloso, Antofagasta, was surveyed from 1990 to 2004. Four stations were sampled: B1, B3, and B5 (60 m depth) and B6 (at $50 \mathrm{~m}$ depth) (Fig. 1). Sampling (4 replicate samples) was carried out by

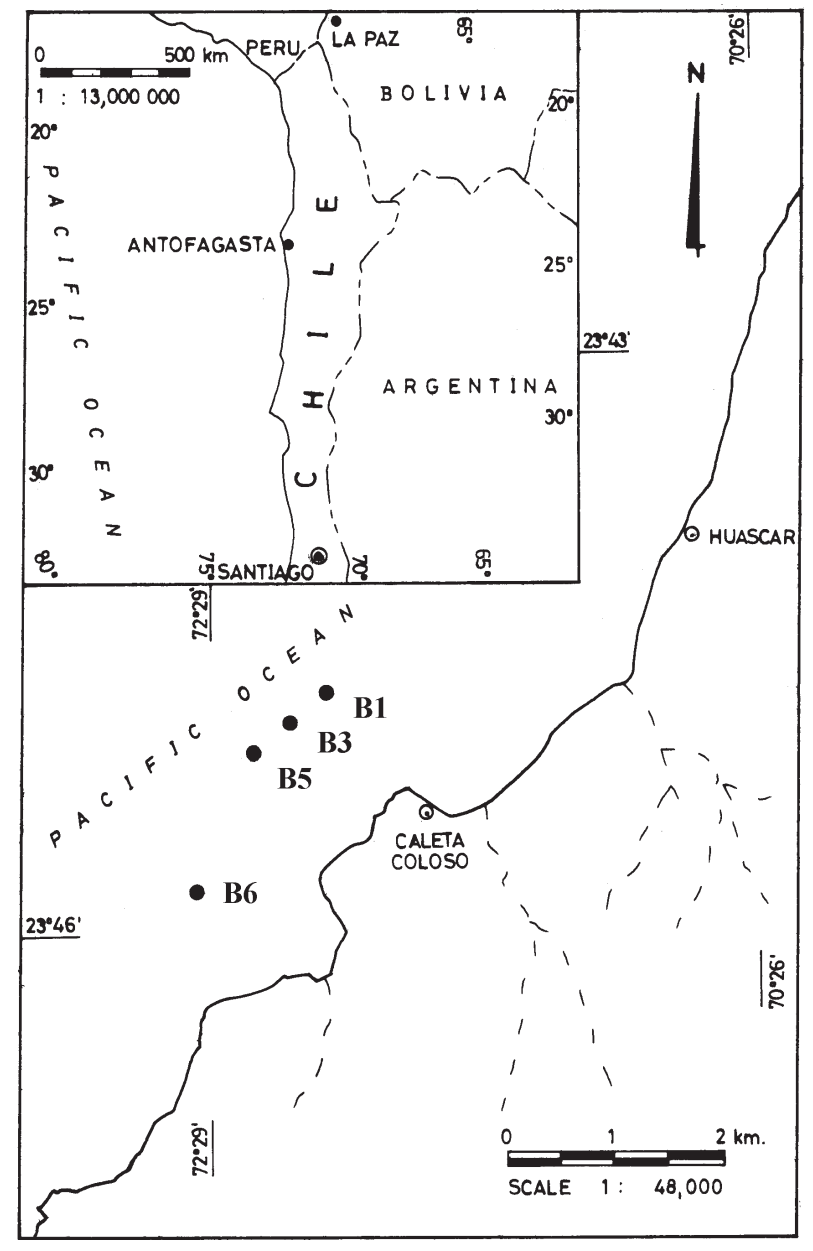

FIG. 1. - Map of sampling sites (B1, B3, B5 and B6) off Punta Coloso, Antofagasta, northern Chile.

means of a $0.1 \mathrm{~m}^{2}$ Petersen grab in two annual cruises (summer and winter). Sediment grain size analysis and total organic matter were determined from samples collected strictly for this purpose.

Grab contents, mostly sandy sediments, were preserved on board, without sieving, in a $10 \%$ solution of buffered formaldehyde and stored in plastic bags. In the laboratory, grab samples were sieved through a $500 \mu \mathrm{m}$ mesh, stained with Rose Bengal and washed. Later, the biological material was transferred to $70 \%$ ethanol for sorting and identification. Polychaetes were sorted into major taxa and then to the species or lowest possible taxonomic level. Biomass was estimated as ash-free-dry weight (AFDW) following the procedures described by Crisp (1971).

Total organic matter was estimated as loss of weight after ignition of dried material in a furnace for two hours at $550^{\circ} \mathrm{C}$ (Buchanan, 1971). Sediment grain analysis was performed by sieving the larger 
grain fraction and by pippeting the silt-clay fraction (Buchanan, 1971). Particle size data were analysed according to Folk (1974).

Biological data were used in bivariate and multivariate analyses to assess spatial and temporal patterns in species composition. Species diversity was determined using the Shannon-Wiener function $\mathrm{H}^{\prime}$ (Pielou, 1966): $\mathrm{H}^{\prime}=-\Sigma \mathrm{p}_{\mathrm{i}} \ln \mathrm{p}_{\mathrm{i}}$, where $\mathrm{p}_{\mathrm{i}}=\mathrm{n}_{\mathrm{i}} / \mathrm{N}$, and the results were analysed by a jack-knife analytical procedure to obtain bias and variance (Magurran, 1988; Sokal and Rohlf, 1995). Furthermore, species accumulation, rarefaction curves (Sanders, 1968; Hurlbert, 1971; Gray, 2002) and Chao 1 (Foggo et al., 2003) estimator curves were also plotted using EstimateS software (Colwell, 2001).

Convergence of similarity pattern deriving from sites and from species were further explored using Correspondence Analysis (CA) (Gauch, 1982; ter Braak, 1987). In this analysis, simultaneous site and species ordinations allowed examination of the ecological interrelationships between sites and species in a single analysis. Statistical and graphic computations were mainly performed using the SYSTAT package (Wilkinson, 2000).

\section{RESULTS}

\section{Sedimentary Substrate}

The results of the particle size analysis are shown in Table 1. Grain sizes were mostly medium sand and the sediments were moderately sorted sediments
TABLE 1. - Mean granulometric parameters, in phi $(\phi)$ scale, for the median, mean, and phi deviation measure (sorting), and total organic matter (TOM) content of the sediments at the four benthic stations off Punta Coloso, Chile. Standard deviations are in brackets .

\begin{tabular}{lcccc}
\hline Station & B1 & B3 & B5 & B6 \\
\hline Mean & $1.91(0.54)$ & $2.17(0.48)$ & $2.40(0.48)$ & $2.23(0.78)$ \\
Sorting & $0.94(0.24)$ & $0.91(0.20)$ & $0.76(0.29)$ & $0.84(0.35)$ \\
TOM & $6.29(2.09)$ & $5.56(1.47)$ & $5.06(1.04)$ & $3.64(1.49)$ \\
\hline
\end{tabular}

reflecting moderate wave and current activity (or energy) in this marine area. The total organic matter content (TOM) of the sediments was relatively high for an open coast, with mean values ranging from $3.64 \%$ at the shallowest station (B6) to $6.29 \%$ (B1).

\section{General hydrography of the area}

The clear thermocline in summer and occasional stratification in winter demonstrate the marked seasonal differences in temperature that characterize the water column off Punta Coloso. Salinity shows high vertical homogeneity and is characterized by the presence of Subsurface Equatorial Waters with a dissolved oxygen concentration of $<1 \mathrm{ml} / \mathrm{l}$ at the sea bottom (Arcos, D. and S. Nuñez, pers. comm.). In 1991-1992, the thermal anomalies of the ENSO warm phase caused the thermocline to deepen to around $50 \mathrm{~m}$ (Fig. 2) with a temperature of $14^{\circ} \mathrm{C}$; the thermocline returned to $25 \mathrm{~m}$ depth during the cold phase known as la Niña. In 1997-1998, the thermocline deepened to $60 \mathrm{~m}$ with a maximum temperature of $19^{\circ} \mathrm{C}$ in association with one of the strongest

\section{Cruise dates}

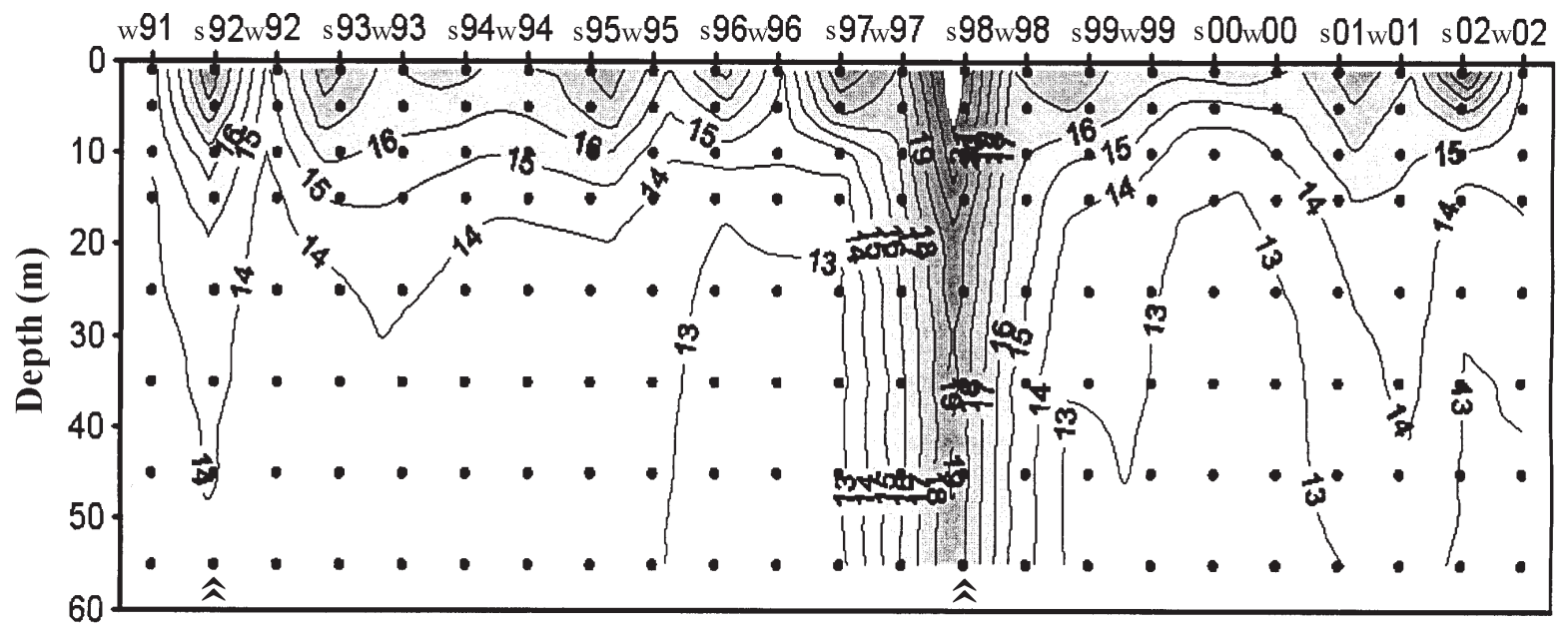

FIG. 2. - Temperature profiles for the sea-water mass encountered off Punta Coloso, during the different hydrographic cruises performed from 1991 to 2002 ( $\mathrm{w}=$ Winter; $\mathrm{s}=$ Summer; » = ENSO warm phase). 
ENSO episodes registered in the 20th Century (Arntz and Fahrbach, 1996). The thermocline returned to normal in 1999, that is, stratification was observed in the first $30 \mathrm{~m}$ of the water column.

\section{Polychaete fauna}

The contribution of the polychaete fraction to total fauna, in terms of numerical abundance, varied for the different cruises, ranging from $65 \%$ (February 2000) to 93\% (February 1993), with a contribution to the total macrobenthic fauna of nearly $83 \%$. Polychaete biomass, on the other hand, made a smaller contribution to the total, ranging from 20\% (August 1997) to approximately 85\% (February 2001). The total number of invertebrate species collected during the 25 cruises was relatively low (44 to 90). The number of polychaete species per cruise was 18 to $37($ mean $=29.9$; s.d. $=4.1)$ and the accumulative total was 56 .

The most abundant polychaetes in this study were Aricidea pigmentata Carrasco (26.49\% of the total), Magelona phyllisae Jones (22.66\%), Paraprionospio pinnata (Ehlers) (13.45\%), Tharyx longisetosa Hartmann-Schröder (12.09\%), Prionospio peruana Hartmann-Schröder (11.8\%), Spiophanes soederstroemi (Hartman) (2.8\%), Pettiboneia wui Carrasco and Palma (2.17\%), and Nephtys ferruginea Hartman (1.23\%). The ecological dominance by five species-over $85 \%$ of the sampled polychaete total-is noteworthy.

\section{Average density and biomass of polychaetes}

Figure $3 \mathrm{a}$ shows variations across time of the total densities as averaged for the four stations. Between August 1990 and February 1992, polychaete numbers increased from ca. 1000 ind./ $0.1 \mathrm{~m}^{-}$ 2 to ca. 2000 ind./ $0.1 \mathrm{~m}^{-2}$. After this, abundance decreased progressively to 650 ind./ $0.1 \mathrm{~m}^{-2}$ in August 1994. A period of moderate oscillations followed, lasting until August 1996 and polychaete numbers remained unstable until February 2000. A new period of instability, greater than that of the mid-1990s, has been observed through February 2004. Seasonal, (winter-summer) variations are hard to discern with such oscillations in abundance.

Figure $3 \mathrm{~b}$ shows the widely fluctuating biomass variations observed during this study. After the March 1991 peak, the still-oscillating biomass values decreased to marked minima in February and
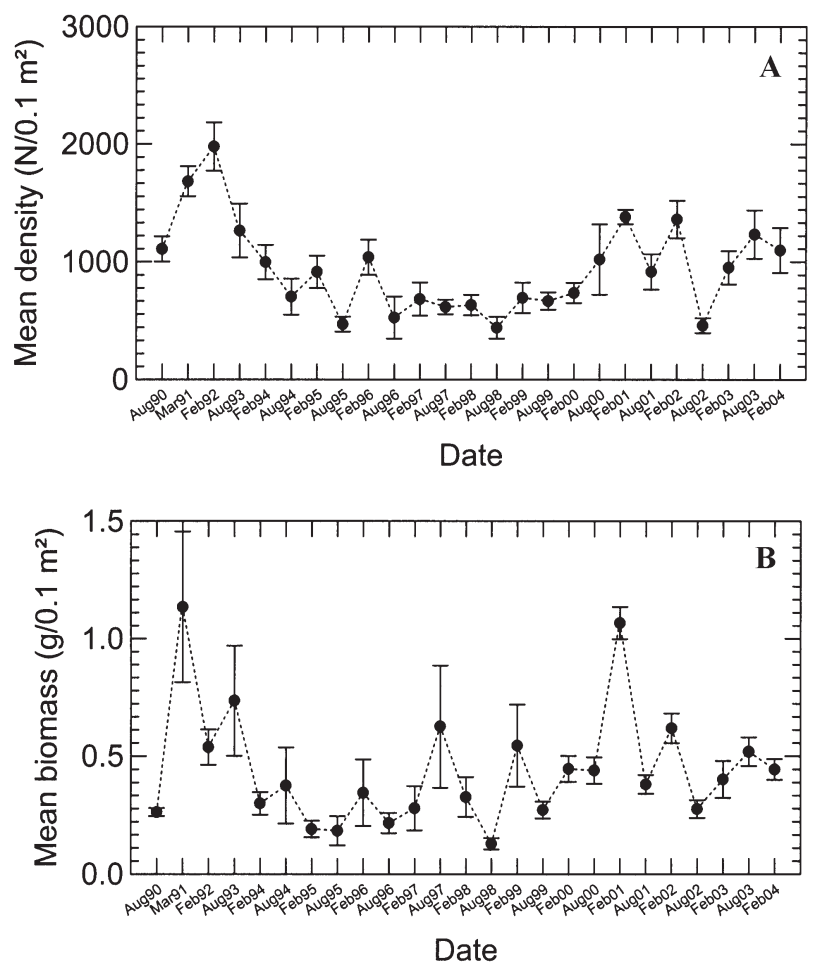

FIG. 3. - (A) Temporal fluctuations of the overall average density $\left(\mathrm{N} / 0.1 \mathrm{~m}^{-2}\right.$ ) and (B) biomass (AFDW $\mathrm{g} / 0.1 \mathrm{~m}^{-2}$ ) for the polychaete fauna collected off Punta Coloso from 1990-2004 (Mean \pm standard error).

August 1995. After these cruises, biomass remained unstable, reaching a secondary maximum in August 1997 before falling to a considerable minimum in August 1998. Still unstable, biomass fluctuated considerably until reaching a maximum in February 2001. Biomass values continued to oscillate widely at end of the study period.

Seasonal variations in numerical abundance for each station can be found in Figure 4. At Station B1, abundance increased between August 1990 and August 1993 and decreased thereafter, reaching a minimum in February 1995. A fairly stable cycle followed, which peaked in February 1997. An unstable cycle was then observed until August 1999, after which an increase began that ended with a February 2002 maximum, giving way immediately to a new period of instability.

Station B3 also began the study with increasing abundance, peaking in February 1992. A clear decrease was seen until the August 1993 cruise, and the following unstable cycle lasted until August 1997. Instability occurred from this date until February 2000, when another highly unstable period began.

Similarly, abundance at Station B5 increased to a noticeable maximum in February 1992. Abundance then decreased noticeably, as seen in the August 

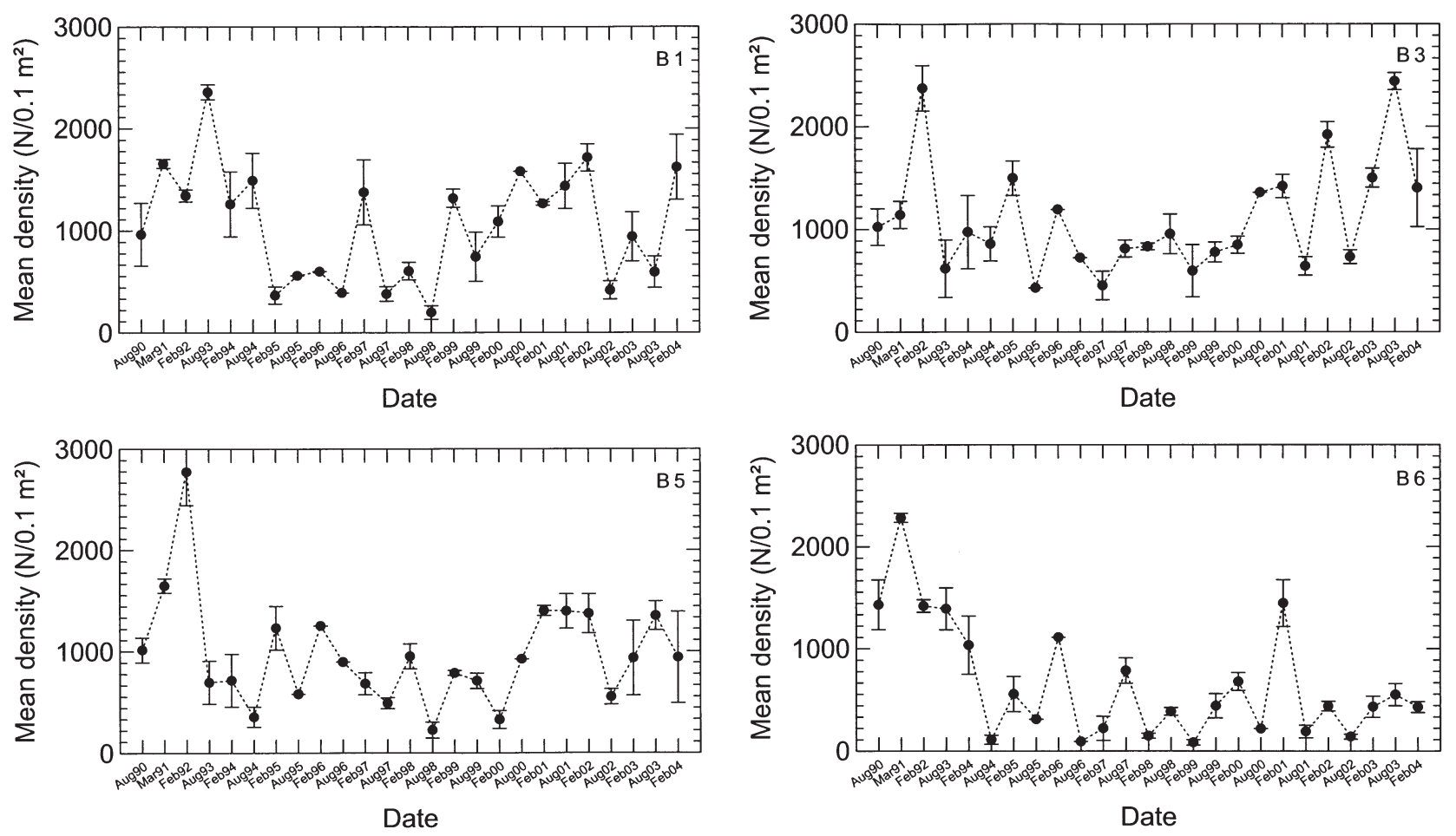

FIG. 4. - Temporal fluctuations of the average density $\left(\mathrm{N} / 0.1 \mathrm{~m}^{-2}\right)$ for the polychaete fauna collected at the four stations (B1, B3, B5, and B6) studied off Punta Coloso from 1990-2004 (Mean \pm standard error).

1993 value, which is comparable to that of February 1994. A long period of instability followed until at least February 2001. Although the abundance values for the February 2001, August 2001, and February 2002 cruises are quite similar, they were followed by a new cycle of instability.

The shallowest station, Station B6, registered high abundances for the first two cruises (August 1990 and March 1991) with clear maxima. The sharp decline that followed reached its lowest point in August 1994. Since then, and apart from the secondary maxima in February 1996 and 2001, relatively stable values and limited cycles were observed throughout the rest of the study period.

\section{Variations of the most abundant polychaetes}

Average density fluctuations of the most abundant species in Punta Coloso are shown in Figure 5. During the study, the four most abundant species were the small polychaetes (adults about $1 \mathrm{~cm}$ long) Aricidea pigmentata, Magelona phyllisae, Prionospio peruana, Tharyx longisetosa and the medium-sized polychaete (adults over $1.5 \mathrm{~cm}$ long) Paraprionospio pinnata.

The most abundant species, A. pigmentata, began the study period with high densities and a March
1991 maximum, although after this date, its numbers fell sharply until August 1993 when abundance began to oscillate. The second most abundant species, M. phyllisae, was moderately abundant during the course of the study. Its average density was unstable throughout nearly the entire study period, although the values did tend to be comparable to or greater than the initial values as of August 2001. Marked maxima were observed in February 1992, February 2003, August 2003, and August 2004 and minima in August 1993 and August 1998.

The third most abundant species, P. pinnata, was highly unstable during the study period. After original moderate abundances, the species failed to appear in the August 1993 and August 1997. Wide oscillations followed with maxima in February 1994 and February 1996, but nearly disappeared in August 1995 and August 1997. This last situation was repeated between August 1997 and February 2000. Events of two notable maxima (February 2001 and February 2002), and two successive marked minima (August 2001 and August 2002) did occur. At the end of the study period, the abundance values were oscillating again.

Although the average density of $P$. peruana was much less significant that those of the aforementioned species, it also fluctuated widely, frequently 

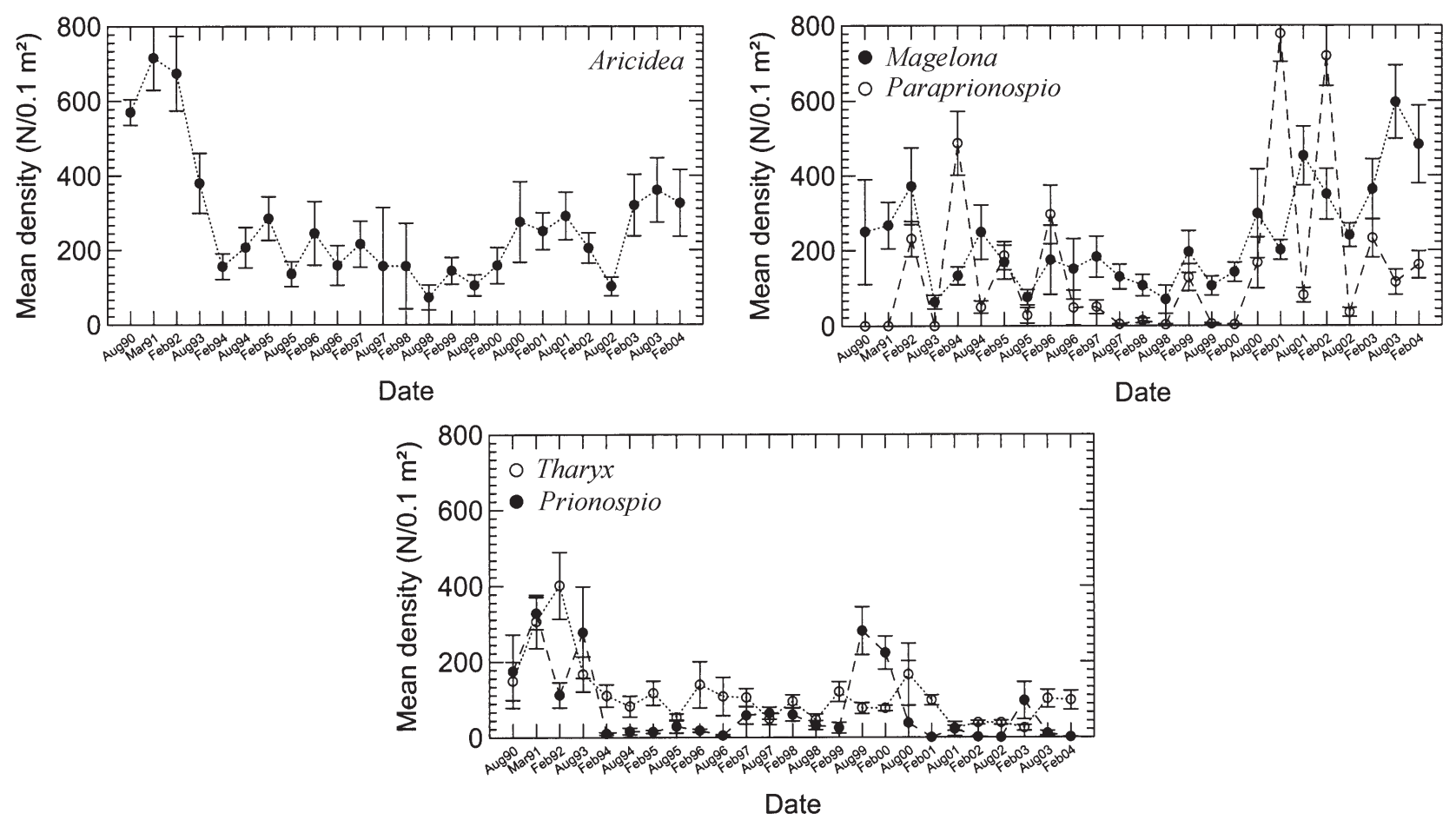

FIG. 5. - Temporal fluctuations of the average density $\left(\mathrm{N} / 0.1 \mathrm{~m}^{-2}\right)$ of the five most abundant species collected off Punta Coloso from 19902004 (Mean \pm standard error).
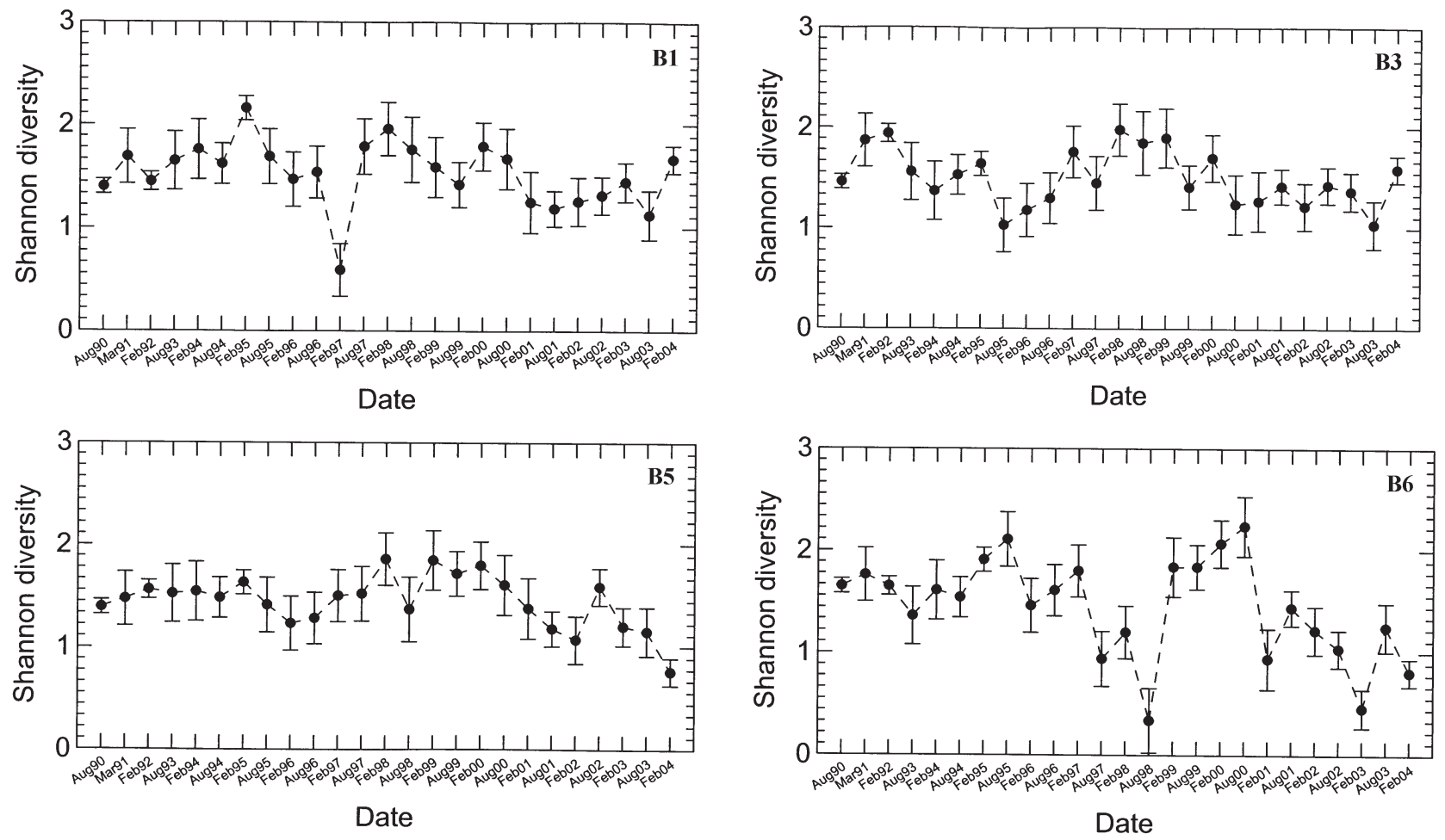

FIG. 6. - Temporal variations (1990-2004) in the polychaete diversity (Shannon H' jack-knifed) collected at benthic stations B1, B3, B5, and B6 (Mean \pm standard error).

disappearing from the samples or appearing with very low abundances (February 1994, August 1996, February 2001, February 2002, August 2002 and
February 2004). Finally, T. longisetosa appears in the early samples with relatively important abundances and reaching a maximum in February 1992. 


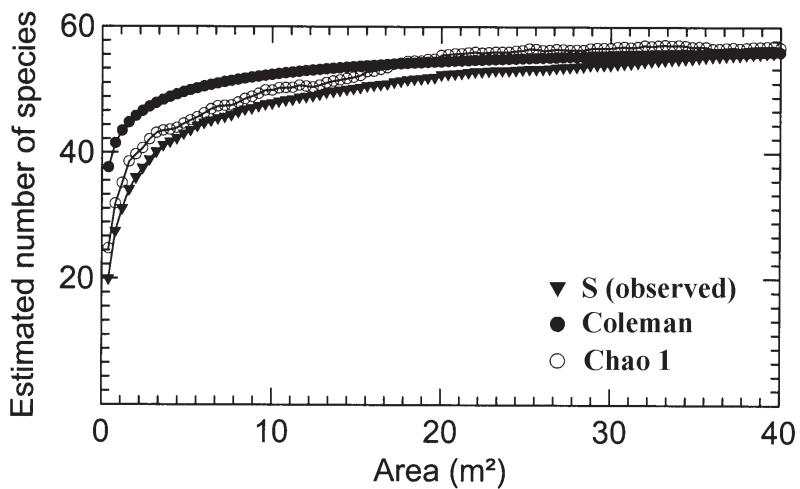

FIG. 7. - Species accumulation, rarefaction (Coleman) and Chao 1 curves for the polychaete fauna off Punta Coloso. S (observed) is the mean estimated number of species after 50 randomisations of the data for each sample size and accumulated up to the total sample size.

\section{Polychaete diversity}

Trends in polychaete species diversity are given in Figure 6. In general, the $H^{\prime}$ values were moderate to low, varying between 0.34 and $2.24 \mathrm{H}^{\prime}$ during the entire study period.

The H' values for Station B1 fluctuated between 0.59 and $2.16 \mathrm{H}^{\prime}$, giving way to a slight but steady increase in values through August 1994 and a sudden peak in February 1995. Thereafter, values decreased to a severe minimum in February 1997, when $T$. longisetosa was clearly dominant. H' values at Station B3 varied between 1.03 and 1.98, increasing in February 1992 and February 1998 and showing two minima in August 1995 and August 2003. Station B5 began the study with fairly stable diversity values, reaching weak maxima in February 1995, February 1998 and February 1999. Important minima were observed in February 2002 and February 2004.

Station B6 was highly unstable throughout the study period; diversity fluctuated widely, with marked maxima and minima.

Figure 7 shows species and rarefaction accumulation curves for the study area. The geometric shapes of the curves are fairly comparable to relatively low slopes and correspond to a low number of expected species, always less than 60 species per 40 $\mathrm{m}^{2}$ of sampled surface. Coleman's rarefaction curves and, to a lesser degree, those of Chao 1 display an important overestimation of the expected number of species compared with the species accumulation curves. For small-sized samples, i.e., less than $2 \mathrm{~m}^{2}$, overestimation is near $100 \%$ of the number estimated for the species accumulation curve.

\section{Ordination analysis}

Figure $8 \mathrm{a}$ shows the graph produced by the Correspondence Analysis of the 100 benthic cruise stations (4 stations over 25 cruises) studied off Punta Coloso between 1990-2004. The first axis represents $39.1 \%$ of the total variance and the second $26.4 \%$. Although in the Euclidean plane, the graph reveals the presence of a larger group of sites/dates, at least 15 of these (viz., 1, 13, 17, 21, 25, 29, 37, 41, 45, 49,
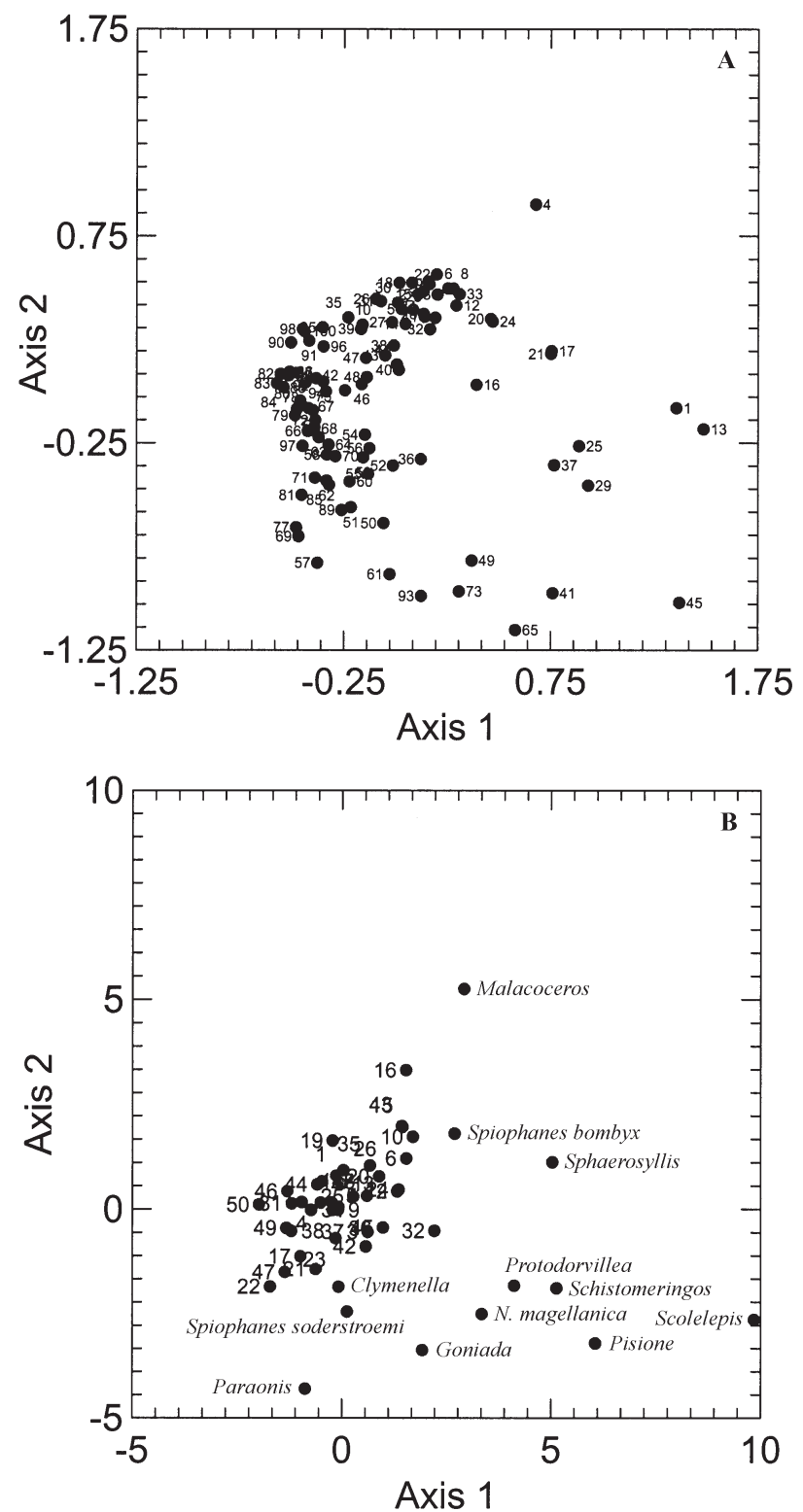

FIG. 8. - Correspondence Analysis ordination of (A) the 100 datesites samples (1-100) (4 stations over 25 cruises), and (B) polychaete species, from Stations B1, B3, B5, and B6 (Axis I = 39.1\% of variance and Axis II $=26.4 \%$ ) off Punta Coloso studied from 1990 to 2004. Date-sites numbers 1, 13, 17, 21, 25, 29, 37, 41, 45, $49,57,61,65,73$ and 93 (A) belong to station B6 and genera names (B) correspond to species also mainly associated with station B6. 
57, 61, 65, 73, and 93), all samples collected from Station B6, appear to be disperse and not in line with the larger group. This is due to the environmental heterogeneity of the site, which is more shallow, sandy, and coastal than the other three stations, which share a muddier, deeper environment.

The same analysis is shown for species in Figure $8 \mathrm{~b}$. A larger, central group of species was observed with some species more dispersed, mainly Malacoceros sp., Spiophanes bombyx, Sphaerosyllis sp., Pettiboneia wui, Clymenella fauchaldi, Spiophanes soederstroemi, Schistomeringos sp., Scolelepis quinquedentata, Nepthys magellanica, Goniada peruana, Paraonis sp. and Pisione sp. The larger central group was made up of polychaetes of high and medium numerical abundances, reflecting a high affinity for the larger group of stations and persistent stability throughout the study period. The species named above are those most associated with the more shallow, coastal station (B6), which has heterogenous bottoms.

\section{DISCUSSION}

The sublittoral marine bottoms off Punta Coloso are dominated by medium sands and moderately sorted sediments, reflecting a moderate energy regime. The relatively high values of total organic material (TOM) in the sediments are consistent with the region's high biological productivity, indicated previously by Carrasco $(1997,1998)$ and comparable to the values reported by Tarazona et al. (1988a) for sediments on the shallow central Peruvian shelf.

The number of observed polychaete species is comparable to those reported at similar latitudes in the Northern Hemisphere (Knox, 1977). The polychaete fauna is dominated principally by small-sized forms and interface consumers (Thagon and Greene, 1992), a frequent condition in marine macrobenthos, as indicated by Beukema (1988) for the Dutch Wadden Sea and Tarazona et al. (1988a, 1988b, 1996) for Peru's continental shelf, which is dominated by small polychaetes such as M. phyllisae, Owenia collaris, and Leitoscoloplos kerguelenis chilensis as well as the medium-sized $P$. pinnata. With the exception of the absence of $O$. collaris in their samples and the highly abundant presence of $A$. pigmentata in Punta Coloso, the Tarazona results are similar to ours.
The most dominant species collected off Punta Coloso persisted throughout the study period, which is remarkable considering the region's environmental variability (Bernal et al., 1985) and the study's shallow shelf depths. These species showed marked temporal fluctuations, including the disappearance of some from samples taken on some cruises or on particular sampling dates (e.g. Paraprionospio pinnata and Prionospio peruana).

The numerical abundance of polychaetes is here considered to be moderate to high, within the ranges reported, for example, for Cape Cod Bay (Young and Rhoads, 1971). The numbers fluctuate irregularly, with prominent maxima and minima at the four stations and no clear trends. Although both El Niño events that took place during the study period, one in 1991-1992 and especially the very strong event in 1997-1998 (see Figure 2), brought a series of consequences to the region, changes were not observed in the benthic assemblages that could be clearly associated with these phenomena. The estimated polychaete biomass was moderate and within the ranges reported for Cape Cod (Young and Rhoads, 1971), England's Northumberland coast (Buchanan and Warwick, 1974), and the South Orkney Islands (Hardy, 1972). Temporal fluctuations in polychaete biomass were also irregular, unstable, with marked maxima and minima, and lacking clear patterns or trends, reflecting the distinct life cycles and characteristics of the species involved.

The number of polychaete species, as stressed earlier, was moderate considering the sampling effort, i.e. $40 \mathrm{~m}^{2}$ area. The mean numbers of species per station fluctuated appreciably during the study period, with marked maxima and minima, ranging from 9 to 24 species per cruise. There was no clear or consistent temporal pattern. Polychaete species diversity showed moderate to low Shannon-Wiener' $\mathrm{H}$ ' values, which fluctuated moderately, and the lowest values of the index reflected the marked numerical dominance of a very few species. These fairly depressed diversity values are also reflected in the estimated number of species; the curves for the observed number of species, rarefaction (Coleman), and Chao 1 never exceeded 60 species and exhibited low slopes.

When analyzing temporal variations in the pooled polychaete abundance (entire study area or different studied sites), it was not possible to detect annual or seasonal patterns, which were detected, for example, by Buchanan et al. (1978) off the 
Northumberland coast and by Pearson et al. (1986) in Scottish sea lochs and Dauvin and Ibanez (1986) in the Baie de Morlaix, north coast of France. From the analysis of Figure 2 and Figure 3 the increase of water temperatures in the last warm ENSO phases (1991-92 and 1997-98) can be observed, where the latter event coincides with an important minima of the density and biomass of polychaetes.

Buchanan and Moore (1986) suggested that progressive temporal changes in the community structure parameters are regarded as being attributable to some facet of environmental change or perturbation, which will suggest the lack of important environmental disturbances in this area.

At each of the four stations sampled off Punta Coloso, the same abundant polychaete species were always present and dominated the samples. The exceptions were $P$. peruana and $P$. pinnata, which, in some instances, fluctuated widely, almost to the point of disappearing in some cruises or dates. The former species is more associated with Station B6 and, over time, has come to be found nearly exclusively in this shallower, coastal station. The latter worm, which showed profound numerical fluctuations, is more associated with the three deepest stations. When individual numerically dominant species are analyzed over time, it is not possible to observe certain trends in a seasonal pattern, except in the case of $P$. pinnata, whose abundance reflects an annual reproductive cycle with juveniles recruiting actively in the austral summer, as reported in Carrasco and Arcos (1980) for central Chile. Here, two dominant species, i.e. A. pigmentata and $M$. phyllisae, could have two generations per year as suggested earlier by the senior author for more southern Chilean waters, making it impossible to observe regular cycles in the samples, which were collected on a strictly summer-winter basis.

All the above factors suggest high ecological stability for the polychaete fauna, both as high persistence or constancy over time and also, in part, as high inertia when facing disturbances (Boesch and Rosenberg, 1981).

The resulting high affinity or similarity between the cruise station samples in the correspondence analysis ordination revealed one major station group, suggesting a single and similar polychaete benthic assemblage off Punta Coloso through time. The samples departing from this scheme correspond to Station B6, the shallowest and most coastal site, which has heterogeneous bottoms of sandy patches surrounded by rocky bottoms. It is very difficult to operate a grab here, and the faunal assemblages tend to distance themselves from deeper sites. Thus, samples from Station B6 include some forms or species that are observed, if at all, in lower numbers at the three other stations.

As stressed elsewhere, another purpose of ordination when summarizing community data is to relate community variation to environmental gradients (Gauch, 1982). The mentioned ordination, which determined the presence of only one sitegroup and an unique species-group is indicating the non-existence of a clear environmental gradient. Therefore, the new evidence presented here, which has the advantage of a much longer time period, allows us to corroborate and validate the suggestion of Carrasco (1997) that the marine environment where this polychaete assemblage dwells will be stable, without exhibiting clear seasonal or annual patterns that could be explained by the special action of some environmental variable.

\section{ACKNOWLEDGEMENTS}

This study was supported by funds from the Environmental Program of Minera Escondida Ltda., Antofagasta, Chile. The authors are very grateful to Sergio Núñez for the analysis of hydrographic data and to Luis Aburto for help in collecting and sorting benthic samples.

\section{REFERENCES}

Arntz, W.E. and E. Fahrbach. - 1996. El Niño: experimento climático de la naturaleza. Fondo de Cultura Económica, Ciudad de México, México.

Arntz, W.E., J. Tarazona, V.A. Gallardo, L. Flores and H. Salzwedel. - 1991. Benthos communities in oxygen deficient shelf and upper slope areas of the Peruvian and Chilean Pacific coast, and changes caused by El Niño. In: R.V. Tyson and T.H. Pearson (eds.), Modern and Ancient Continental Shelf Anoxia, pp. 131154. Geological Society Special Publication 58, London.

Bernal, P., F. Robles and O. Rojas. - 1985. Variabilidad física y biológica en la región meridional del sistema de Corriente del Perú. Monograf. Biol., 2: 75-102.

Beukema, J.J. - 1988. An evaluation of the ABC method (abundance/biomass comparison) as applied to macrozoobenthic communities living on tidal flats in the Dutch Wadden Sea. Mar. Biol., 99: 425-433.

Boesch, D.F. and R. Rosenberg. - 1981. Responses to stress in marine benthic communities. In: G.W. Barret and R. Rosenberg (eds.), Stress effects on natural ecosystems, pp. 179-200. Wiley \& Sons, New York.

Boesch, D.F., M.L. Wass and R.W. Virnstein. - 1976. The dynamics of estuarine benthic communities. In: M. Wiley (ed.), Estuarine processes, pp. 179-200. Academic Press, New York.

Buchanan, J. - 1971. Measurements of the physical and chemical 
environment. In: N. Holme and A. McIntyre (eds.), Methods for the study of marine benthos, pp. 30-58. IBP Handbook 16. Blackwell Science Publications, Oxford.

Buchanan, J.B. and J.B. Moore. - 1986. A broad review of variability and persistence in the Northumberland benthic fauna 1971-85. J. Mar. Biol. Assoc. U.K., 66: 641-657.

Buchanan, J.B. and R.M. Warwick. - 1974. An estimate of benthic macrofaunal production in the offshore mud of the Northumberland coast. J. Mar. Biol. Assoc. U.K., 66: 641-657.

Buchanan, J.B., M. Sheader and P.F. Kingston. - 1978. Sources of variability in the benthic macrofauna off the south Northumberland Coast. J. Mar Biol. Assoc. U. K. 58: 191-209.

Carrasco, F.D. - 1997. Sublittoral macrobenthic fauna off Punta Coloso, Antofagasta, northern Chile: high persistence of the polychaete assemblage. Bull. Mar. Sci., 60: 443-459.

Carrasco, F.D. - 1998. Macrobentos marino y vigilancia ambiental: El sublitoral de fondos blandos de Punta Coloso. In: D. Arcos (ed.), Minería del cobre, ecología y ambiente costero, pp. 245275. Editora Aníbal Pinto, Concepción.

Carrasco, F.D. and D. Arcos. - 1980. Estimación de la producción secundaria de Paraprionospio pinnata (Spionidae, Polychaeta) frente a Bahía de Concepción, Chile. Bolm. Inst. Oceanog., S. Paulo, 29: 245-248.

Colwell, R.K. - 2001. Estimates: statistical estimation of species richness and shared species from samples. Version 6. User's guide and application (hhtp://viceroy.eeb.uconn.edu/estimates).

Crisp, D.J. - 1971. Energy flow measurements. In: N. Holme and A. McIntyre (eds.), Methods for the study of marine benthos, pp. 197-279. IBP Handbook 16. Blackwell Science Publications, Oxford.

Dauvin, J.-C. and F. Ibanez. - 1986. Variations à long-terme (19771985) du peuplement des sables fins de la Pierre Noire (baie de Morlaix, Manche occidentals): analyse statistique de l'évolution structurales. Hydrobiologia, 142: 171-186.

Foggo, A., M.J. Atrill, M.T. Frost and A.A. Rowden. - 2003. Estimating marine species richness: an evaluation of six extrapolative techniques. Mar. Ecol. Prog. Ser. 248: 15-26.

Folk, R. - 1974. Petrology of sedimentary rocks. Hemphills, Publishing Co., Texas.

Gauch, H.G. - 1982. Multivariate analysis in community ecology. Cambridge University Press, Cambridge.

Gray, J.S. - 2002. Species richness of marine soft sediments. Mar. Ecol.Progr. Ser., 244: 285-297.

Hardy, P. - 1972. Biomass estimates of some shallow-water infaunal communities at Signy Island, South Orkney Islands. Brit. Antarctic Survey, Bull., 31: 93-106.

Holland, A.F. - 1985. Long-term variation of macrobenthos in a mesohaline region of Chesapeake Bay. Estuaries, 8(2A): 93-113.

Hurlbert, S.H. - 1971. The nonconcept of species diversity: a critique and alternative parameters. Ecology, 52: 577-586.

Knox, G.A. - 1977. The role of polychaetes in benthic soft-bottom communities. In: D.J. Reish and K. Fauchald (eds), Essays on Polychaetous Annelids in memory of Dr. Olga Hartman, pp. 547-604. Allan Hancock Foundation, Los Angeles.

Lie, U. and R.A. Evans. - 1973. Long-term variability in the struc- ture of subtidal benthic communities in Puget Sound, Washington, USA. Mar. Biol., 21: 122-126.

Lewontin, R.C. - 1969. The meaning of stability. Brookhaven Symposia in Biology, 22: 13-24.

Magurran, A.E. - 1988. Ecological diversity and its measurements. Chapman \& Hall. London.

Margalef, R. - 1969. Diversity and stability: a practical proposal and a model of inter-dependence. Brookhaven Symposia in Biology, 22: 25-37.

Pielou, E.C. - 1966. The measurements of diversity in different types of biological collections. J. Theoret. Biol., 13: 131-144.

Pearson, T.H., G. Duncan and J. Nutall. - 1986. Long term changes in the benthic communities of Loch Linnhe and Loch Eil (Scotland). Hydrobiologia, 142: 113-119.

Probert, P.K. - 1984. Disturbance, sediment stability, and trophic structure of soft-bottom communities. J. Mar. Res., 42: 893-921.

Sanders, H.L. - 1968. Marine benthic diversity: a comparative study. Am. Nat., 102: 243-282.

Sokal, R. and J.F. Rohlf. - 1995. The principles and practice of statistics in biological research. W.H. Freeman \& Company, New York.

Tarazona, J., H. Salzwedel and W. Arntz. - 1988a. Oscillations of macrobenthos in shallow waters of the Peruvian central coast induced by El Niño 1982-83. J. Mar. Res., 46: 593-611.

Tarazona, J., H. Salzwedel and W. Arntz. - 1988b. Positive effects of "El Niño" on macrozoobenthos inhabiting hypoxic areas of the Peruvian upwelling system. Oecologia, 76: 184-190.

Tarazona, J., W. Arntz and E. Canahuire. - 1996. Impact of two "El Niño" events of different intensity on the hypoxic soft bottom macrobenthos off the Central Peruvian coast. Mar. Ecol., 17(13): 425-446.

ter Braak, C.F.J. - 1987. Ordination. In: R.H.G. Jongman, C.F.J. ter Braak and O.F.R. van Tongeren (eds), Data analysis in community and landscape ecology: 91-173. Pudoc, Wageningen.

Thagon, G.L. and R.R. Greene.- 1992. Utilization of deposited and suspended particulate matter by benthic "interface" feeders. Limnol. Oceanogr., 37(7): 1370-1391.

Thrush, S.F. and P.K. Dayton. - 2002. Disturbance to marine benthic habitats by trawling and dredging: implications for marine biodiversity. Annu. Rev. Ecol. Syst., 33: 449-473.

Widdicombe, S. and M.C. Austen. - 2001. The interaction between physical disturbance and organic enrichment: An important element in structuring benthic communities. Limnol. Oceanogr., 46(7): 1720-1733.

Wilkinson, L. - 2000. SYSTAT: The System for Statistics. Systat Inc., Evanston.

Young, D.K. and D.C. Rhoads. - 1971. Animal sediment relations in Cape Cod Bay, Massachusetts. I. A transect study. Mar. Biol., 11: 242-254.

Zajac, R.N., R.B. Whitlatch and S.F. Thrush. - 1998 Recolonization and succession in soft-sediment infaunal communities: the spatial scale of controlling factors. Hydrobiologia, 375/376: 227-240.

Received September 20, 2004. Accepted September 5, 2005. 